\title{
The Spatial Symbolismin Ghassan Kanafani's Novel " Three Letters from Palestine: An Analytical Study
}

\author{
Dr Nawal Al-Sheikh \\ Faculty of Humanities \\ Department of Languages
}

\begin{abstract}
:
The researcher in this research paper explores and explains the symbolism of the place where the events took place in Ghassan Kanafani's novel titled The Three Letters from Palestine. The researcher adopted the qualitative approach in an attempt to examine the symbolism of the spatial element in Three Letters from Palestine and its significance and the deep meaning behind the literal meaning of these symbols. The research reveals the symbolism of place employed in Kanafani's short story, through which he explains his connection to the homeland and concepts related to the Palestinian cause such as belonging to the place, identity, and the Palestinian heritage. This narrative method is one of the methods adopted by Kanafani in his writing, which was intended to link the reader with the events of the short story and its spatial elements.
\end{abstract}

Keywords: Ghassan Kanafani, Symbolism, three letters from Palestine, Gaza, Ramla, Tira.

\section{INTRODUCTION}

The place in any literary work attracts the attention of researchers and critics as an important pillar in the construction of the work of fiction and composition. As the relationship between man and place is a long-standing controversial relationship, the place is a repository of the storyteller's memories of childhood, youth, adventures, pain, sorrows of love, and joys. It is the most comprehensible tool for the meaning and art of the text.

Habib N. and Australia S.describein The Land of the Sad Oranges, as the second story of the Palestinian writer Ghassan Kanafani and published in 1962, that Kanafani merges the aesthetics with the historical realities in this novel. Though it tells the sorrow of a medium-size family, it is an example of thousands of displaced families who have suffered as a result of the 1948 disaster of the Palestinians following the Arab army's defeat and the founding of the State of Israel.( Habib N. and Australia S.) This collection is about 120 pages divided into eight stories. Kanafani in this collection painted the many facets of the tragedy of the Palestinians as if he wanted the story to be a mirror of reality and memory, and the language that is a set of multiple curves in the face of the human pain embodied in this mirror, as if the Palestinians could not be freed from their memories in the moments of stupor in the tragedy, or as if this memory would be the gate through which to discover the only possible path to itself (Eid H. 2020).

This collection consists of:

1. The story "Beyond the Border".

2. The story "The horizon behind the gate".

3. The story "The Forbidden Weapon".

4. The story "Three Letters from Palestine".

5. The story "Green and Red".

6. The story "The Land of Sad Orange".

7. The story "Killed in Mosul".

8. Story of "Nothing".

In these stories, the emergence of place element is employed clearly, as if there is a difference in the place from one story to another, where there are in this collection several places that have inspirations and connotations and their 
DOI: $\underline{10.51386 / 25815946 / i j s m s-v 4 i 5 p 101}$

Volume: 4 Issue: 5

September to October 2021

https://www.ijsmsjournal.org

symbolism that carry the lives of the Palestinian people under the existence of settlement and occupation and the suffering of the Palestinian refugees. Since symbolism is an important element in any literary work, the researcher devotes his work to highlight Kanafani's works as an example of resistance literature. According to Collins dictionary, symbolism is the use of symbols to represent something (Collins Dictionary 2014)

This research relies on the mechanics of the historical method by tracking some phenomena, starting from the place in the old philosophy of the West and the Arabs moving to the place in the modern philosophy, in addition to the events known to the Palestinian cause, which is represented in the historical and political conflict, and we rely on this approach. This is to review the history of the development of Israeli policy and its actions affecting the Palestinian cause which is reflected and embodied in the Palestinian literature and was the concern of the Israeli politicians as what happened with Mahmoud Darwishwhen the Israeli Minister of Education recommended teaching Darwish's poems at the Israeli schools (Darwish, M. 2000). We have not overlooked the mechanisms of the analytical descriptive approach to present this case as it is in reality, as the descriptive approach here is complementary to the historical approach, and that both serve our topic.

\section{Statement of the Study}

The problem of the study lies in determining the symbolism of the place in the story of three letters from Palestine, a story in a collection of stories of The Sad Land of Orangesby Ghassan Kanafani, through which he drew a great link between the place and personalities to illustrate the suffering of the Palestinian people, During the stand on the places mentioned in the novel and clarify the symbols intended by the author and their association with the characters of the novel mentioned.

\section{Significance of the Study}

We have been motivated by the critical importance of the place in the novel to present the subject of the place in the Palestinian story and specifically in the stories of Ghassan Kanafani. On the other hand, the story is expanding my knowledge and, and the reason for choosing the story is the desire to curb the curiosity that we have been directed towards, in addition to the "Land of Sad Oranges" talks about the stage of the Palestinian people, especially the study of the story of Three Letters from Palestine is almost absent and did not receive the interest of researchers and scholars.

\section{The Questions of the Study}

This paper is an attempt to answer the following questions: How the place was reflected in the collection of short stories? What are its forms? What significance does it hold? We also sought to answer what is the place and what is its role in shaping narrative construction? And how Kanafani hired the place? What are the open and closed places in the story and their implications?

\section{LITERATURE REVIEW}

In this section, the researcher presents some studies related to the chosen story and the author's works to highlight the significance of the current study. Unfortunately, few English studies were found on Kanafani's works. Therefore, the researcher considers the current study a unique one due to the lack of sources and studies to rely on.

Ghassan Kanafani is a Palestinian novelist, storyteller and journalist. He was born in Acre in northern Palestine (April 9-1936 AD) and lived in Jaffa until the Nakba in 1948. He devoted his life to the Palestinian cause. His literary works embodied the suffering of his people with the Zionist occupation and alienation. The last chapter of his story was dedicated to Palestine. Until his early death, he had published 18 books and wrote hundreds of articles and studies on culture, politics, and the struggle of the Palestinian people. Most of his literary works have been translated 
DOI: $\underline{10.51386 / 25815946 / i j s m s-v 4 i 5 p 101}$

Volume: 4 Issue: 5

September to October 2021

https://www.ijsmsjournal.org

into 17 languages and published in more than 20 countries. Two of his novels have been transformed into two cinematic films (Abdul Hadi, M. 2006)

In their study, Elmahdi, Omer \& Hezam, Abdulrahman tried to examine the symbolism in Men in the Sun and its significance and the deep meaning behind the literal meaning of these symbols. The study tries to examine the basic symbol of the story "the walls of the tank are not pounded", as these three men die suffocating in the tank, without any of them daring to knock the walls of the tank for help. The symbolism of the non-knocking of the walls indicates the legitimate cry of the Palestinian people conflict, who have suffered from displacement. Other symbols in the novel are also analyzed to show how the writer used them for artistic and political purposes. (Elmahdi, O. and Hezam, A. 2019)

Shadi. N. says that the gritty existence characteristic of Kanafani's work makes his representation of the lives of alienated characters more accurate and more visceral. Kanafani uses philosophical and sociological theories to augment the political nature of his protest fiction, one acting within postcolonial parameters of dispossession to object to different forms of imperialism and diaspora. Therefore, this article explores how global critical frameworks (naturalism and existentialism) enrich the localized contexts essential to any study of postcolonial literature and equally move the traditional national allegory of Kanafani to a more realist/unidealistic level of political indictment against oppression.

Louis Brehony talks about Ghassan Kanafani in detail in his article titled Ghassan Kanafani: Voice of Palestine (1936-1972) and he mentions that Kanafani's themes were indissolubly related to the Palestinian people's struggle throughout their lives. In works like The Land of Sad Oranges, Nakba is depicted graphically (1963) (Brehony 2017).

Dr Muhsen Khan talks about Ghassan Kanafani as a symbol of resistance literature who presented the Palestinian cause at an international and regional level. He says that Kanafani did not limit the term "Resistance Literature" to only eloquent Arabic literature, but also called it popular poetry, which represents the fortress of resistance that cannot be destroyed. (Khan, M. 2017)

\section{BACKGROUND}

In the short story titled Three Letters from Palestine, the first one is a letter from Ramla, the narrator remembers their childhood. When he was nine years old? He forced them to raise their arms and stand in the sun, his wife after the Israelis killed them. He sold them to himself and his interrogators at the time of his interrogation. (nooreladab.com)

The second letteris from Al-Tira telling of an exiled fighter in Damascus who sells cakes, asking the past expressing the positive aspects of the armed struggle, while expressing his dissatisfaction of the Arab heads of state who were in their hands. (alteerah.net)

The third letteris from Gaza telling the exile seeking happiness in America and his friend invited him to return home to fulfil his duty in the struggle against the enemy. Letter from Gaza", a work of short fiction, was written by Ghassan Kanafani in 1956. It was published in translation into English in the 1936-39 Revolt in Palestine by the Tricontinental Society of London in 1980. (Marxists.org)

\section{The places of this story are:}

\section{- The street is a witness to Zionist injustice}

Street configurations may vary according to many factors, from cultural and social to topographic or functional factors. Some may not be found at all outside the cultural context. Many researchers have tried to define and classify such characteristics but a universal consensus seems difficult to achieve (Marshall, 2005). 
DOI: $\underline{10.51386 / 25815946 / i j s m s-v 4 i 5 p 101}$

Volume: 4 Issue: 5

September to October 2021

https://www.ijsmsjournal.org

The street is an integral part of the city and one of the prominent spatial signs in it, which opens the doors and moves through their personalities and receives all segments of society where it gives them full freedom of movement.

In the story of Three Letters from Palestine, Kanafani is at the centre of the public view of the street, giving it another sign: the loss of total freedom of character, and this is what Kanafani said they stopped us in a row on the road that connects Ramleh to Jerusalem, and they asked that we raise our hands in the air. One of the Jewish soldiers said that my mother was keen to put her in front of her to protect her shadow of the July sun. He pulled me out of my hands with extreme violence.

In this text, the storyteller depicts the treatment of Palestinians by the Zionist occupation, regardless of his age or gender. I was nine years old at the time and I saw just four hours ago how the Jews entered Ramla and I could see standing there in the middle of the street. Ramadi How the Jews searched for and took away the jewellery of the elderly and the boys.

The description of the street is linked to the memory of the hero and the tragic events that it stores. "She waved with horrible grief and looked at Fatima, her head dropping forward, and points of blood falling through her black hair to the hot brown ground ".In this text, the street took its dramatic dimension with the sadness and pain of the hero. In this story, the street became a scene of crime and death.

\section{- The shop}

The shop is defined by Merriam Webster as 'a building or room stocked with merchandise for sale. It is also a source of livelihood by which a person gains strength and support his family.

The meaning of this shop is changeable in Kanafani story after it was a normal shop "his wife, which I have long seen in front of his shop waiting to finish food to return to the house empty containers," this text shows us the normal situation that any trader can live in,but this is not what Kanafani wanted to portray because he changed the significance of this conceptto another meaning other than the course of events in this shop. That is just to make it a symbol of the Palestinian revolution "has turned his shop into a store of explosives and weapons,".This context is linked to the spatial shift from which the writer tries to reveal to the readers the extent of human attachment. The relationship between the shopkeeper (Abu Othman) extended to include all the people of the village to do their duty in their struggle against the occupation.

In another scene, Kanafani depicts the courage of the Palestinian man and his steadfastness before the Israeli occupation and the need to sacrifice in the return to the homeland. His wife did not return with a white towel only".In this context, it is worth mentioning the determination of the Palestinian man to be free from this occupation, even if it costs him his life. This is what the hero did in this story, which became a model for the Palestinian man, who ventured his life for his homeland.

Ghassan Kanafani took a great interest in the spatial factor in his stories, as this place was a scene of the event and witnessed, and linked to the struggle as if this place was designed to be a witness to the tragedy of the Palestinians. In his framing of the place, Kanafani relied on realistic places as mentioned by name: Mekor Haim, Hadar Haifa, the Rivanery factory, and Tal Aviv, all of which existed in Palestine before their partition but are currently under Israeli administration.

\section{- Mekor Haim self-sacrifice}

An Israeli colony directly connected to the city of Jerusalem from the south, in this colony a major war took place under the leadership of (Abdul QaderHusseini), who launched an attack on the Jews, and was able to control a large part of it and seize several weapons and ammunition. 
DOI: $\underline{10.51386 / 25815946 / i j s m s-v 4 i 5 p 101}$

GhassanKanafani tells us the memories of the old Palestinian fighter and talks about the facts that preceded the occupation of Palestine. A speech and we were all rushing to know as if we were going to the wedding of God's mercy". This text shows us how brave the Palestinian fighter is, how committed he is to his land and his love for him, and how he was confronting his enemy with all enthusiasm.

The significance of the place is transformed from a dark and frightening image to a bright and luminous image full of joy and happiness. The battle has not always been a place of death and death, but in this scene, the battle is transformed into a hall of celebration, in which the Palestinians triumph over the enemy and regain their land and freedom.

In another scene depicting the case of a soldier who was neglected by the Palestinian authorities", he fought a battle in Mekor Haim and came out with 16 bullets in the back that caused his paralysis, and then spent four years after suffering, you can imagine how the feeling of a paralyzed man spent his life He fights to stand on his feet, he was just looking and then smiling, coming back to think about the twenty-five pounds that he needs every day".

The connotation of the place is shifting from the struggle and steadfastness in front of the Israeli army and fighting in all ways to the search for treatment to alleviate the pain caused by the battle.

In another scene, Ghassan Kanafani depicts the suffering of Ibrahim Abu Dayah. "Ibrahim Abu Dayah was dying and three men were standing beside his bed crying, and Ibrahim asked them in a soft voice to sing for him a homeland hymn. He was very tortured and who was near his bed while he was dying? Didn't I tell you that no one cared about the heroes and kept them?"Ghassan Kanafani criticizes bureaucrats who only talk about Palestine; they smoke cigarettes and do not care about the heroes who sacrificed their lives for the homeland.

\section{- "Haifa Mill" martyrdom in the path of the homeland}

This mill is the main breadwinner for Palestinian farmers to sell wheat products, but the Israeli army looted and seized it, displaced its workers and turned it into a mill for bloodshed, killing innocent people.

Ghassan Kanafani depicts the injustice that the Palestinians receive in his country and the suffering they suffer from the Jews who robbed him of his property and land.

Here, we find that the significance of the place is changing after what was a source of livelihood and turn into a Hadar Haifa was a place of death where people die, and this is what we see in the saying, a large mill kills people in the Carmel street without counting in this scene, depicts Ghassan Kanafani The injustice the Palestinians receive in their country and the suffering they suffer from the Jews, who robbed him of his property.

Because of this injustice to the Palestinians, the commander of the Haifa garrison decided to lay down mines that were not large enough to blow up the mill. By a large amount, in this scene, the character is risking his life to obtain a mine.

In another scene, the storyteller depicts the leader's sacrifice for his homeland and the martyrdom in a way that was surprised by a Jewish force that wanted to seize the mine and asked him to God. When the Jews approached to catch him, he fired one shot at the large mine. Ghassan Kanafani depicts us the strong relationship between the Palestinians and the homeland, his attachment to him and his self-sacrifice.

Here the significance of the place is shifted from fear and suffering to the strength and resilience derived from the commander of the Haifa garrison, who sacrificed his life for the homeland after the explosion of the large mine. Ghassan Kanafani criticizes and reprimands officials for not knowing the heroes who are sacrificing for the sake of the homeland without their voices heard until they are martyred.

This is what we see in the saying, "The officials did not maintain their heroes and did not know any assets of the battles, the commander was martyred with his comrades." 
DOI: $\underline{10.51386 / 25815946 / i j s m s-v 4 i 5 p 101}$

Volume: 4 Issue: 5

September to October 2021

https://www.ijsmsjournal.org

\section{- Refinery factory struggle of the Palestinians by all means}

It is a large oil refinery, a source of livelihood for some Arab and Jewish workers working side by side. It is a Jew who threw a grenade at an Arab guard standing at the factory door and killed him.

This place witnessed great sadness over the loss of the Arab guard, this factory has turned into a crime scene and angered the Arab workers, and the workers responded to them by all means

This place witnessed great sadness over the loss of the Arab guard, this factory has turned into a crime scene and angered the Arab workers, and the workers responded to them by all means

We closed the big door of the factory, and then we used to kill all the Zionists, and this is reflected in the telling means, we met that day face to face, and we are both a weapon, and no place can only accommodate manhood, and we were able to overcome them, we were not inside Weapons of any kind, some of us used a tractor and most of us used the long-headed spear and axe.

When all arms are blocked in the face of the Palestinians, they find the axes, shelves and other tools used by the peasants in agriculture. The workers collide with the Jewish workers, after killing the Arab guard, most of whom are new to this type of fighting.

Kanafani hints that the weapon of the Palestinians is an indispensable necessity and that the Palestinians, where he stands on his Palestinian land, can face his enemy with courage. The use of simple weapons in confronting the enemy has a positive significance, as every human being can obtain it, and thus practice the struggle against the Zionists.

Through this scene, Kanafani offers inspirational connotations. The blood that bleeds from the martyr feeds the body of the weapon to give him life and unite with the martyr.

Here the significance of the place is transformed from a place of work and livelihood to a place of battle and bloodshed. Ghassan Kanafani returns to criticize, ridicule and rebuke officials and say that officials did not preserve their heroes, and did not know the origins of the battles. This is a situation in which Palestinians live, criticize officials for not knowing their people, and help them fight for the homeland.

\section{- Tel Aviv}

It is the second-largest Israeli city ever built by Jews after it was taken from the Palestinians and is one of the world's most important cities. A polite warrior, who was a public car driver, saw a Jewish woman fleeing children who were stoning her. He helped her and returned her to her family, but the Jews stole his car, killed him and threw his body.

Ghassan Kanafani depicts the case of the Palestinian warrior and the ugly way he was treated by the Jews. Although he did a heroic job, he died at the hands of the Jews. The writer tries to show us the true image of the Jew, who has no mercy or compassion in his heart, despite the good treatment the Palestinian warrior met with the Jewish woman.

Ghassan Kanafani is resentful of this situation in his homeland, and this is due to the leaders and presidents who govern the country and hold them responsible for the loss of Palestine, as evidenced by saying: "The mistake was not me, it was from above".

In this story, Ghassan Kanafani depicts the ill-treatment of the Palestinians by the Jews and the bitter reality he is living.

Kanafani, when referring to these places, explained certain historical facts utilizing a purely literary technique. He presented the places where the struggle was taking place, and the stages of migration in order, and as a result, the places identified the way of expulsion from the homeland. This way, which Kanafani describes in the story of a leaf.

\section{Al-Shujaeya neighbourhood, childhood memories}

It is one of the largest neighbourhoods in the city of Gaza, and in this story, this place represents the origin where the two friends grew up and lived their childhood. The place where they understood each other as he says he grew up together andeach of us knows the other fully and we pledged to continue together to the end of this. The 
DOI: $\underline{10.51386 / 25815946 / i j s m s-v 4 i 5 p 101}$

Volume: 4 Issue: 5

September to October 2021

https://www.ijsmsjournal.org

neighbourhood is big and their dreams grew up with them. Ghassan Kanafani depicts the close relationship that the two friends have together, how they relate to each other, and what this neighbourhood means for them.

\section{Kuwait is the country of exile.}

This place represents the Palestinian refuge and shelter for them, and a place for livelihood, goodness, and money that they did not find in their homeland Palestine.

What is more difficult for a person to live in a place where only a handful of money is attached to him at the end of the month, and the narrator describes his life in Kuwait by saying 'my life was an empty clingy as a small oyster, loss of heavy loneliness, slow conflict with a mysterious future as the first night, routine rot, a struggle mixed with time, everything was hot, my life was all slippery, they were all parked until the end of the month.'

\section{Gaza the motherland}

This place represents the original country of the narrator, as the hero returned from Kuwait after the flames of the occupation fire at home affected the shining of gold which is originally in exile.

Remarkably, Gaza has witnessed a significant and emotional transformation, when it seemed to her that the hero had reached a closed place, besieged, desolate, a place that is almost unfit for human life, and the narrator described the tragic scene in his saying ' I found Gaza, as it fully pledged, to close as if it was an inner wrapping, wrapped on itself to a rusty crust that the wave threw to the sandy beach near the slaughterhouse, Gaza is narrower than the breath of a sleeper who suffers a horrific nightmare, with a narrow and special odour that cripples it, the smell of defeat and poverty and its houses with protruding outside... this is Gaza.'

The reason that the writer drew this painful, current and tragic picture of Gaza was that he was returning from Kuwait, where the urban civilization, with its tall buildings, luxury homes, and attractive clean beaches.

The pile of stones in Shujaeya neighbourhood has become a symbol of catastrophe instead of its indication, and the narrow alley became a promising beginning to return to historical Palestine, as experienced by the writer's statement:' On the first Shujaeya neighbourhood where we lived, it had a meaning as if I was put there to only nominate it. This is Gaza that we lived in with our good men seven years of the Nakba was a new thing. In the context of this special shift- a shift in the connotation of Gaza. The writer tries to reveal the hidden secret that lies behind man's link to that homeland despite the ravages of occupation, so the writer raises an existential question in his saying. "but what are these mysterious, unspecified matters that attract a man to his family. His house, for his memories, as the spring a lost herd of the mule, I don't know

Really, what makes us hold to a place inhabited by death, fear and suffering? Do we leave a place to an exile inhabited by abundant money? The reason for the shift in the significance of the place in Gaza is related to the feeling of pride, identity, strength resilience that is derived from a vision (Nadia) whose leg amputated alter the occupation bombed her family's home. In her resolve, she is a model of transcendence.

\section{Hospital challenge and resilience}

The events in this place revolve around the disease (Nadia), the hero's niece, who fell ill and went to visit her, but he did not know what her disease was exactly. She is thirteen years old, but she looks older than that due to the severe pain she was suffering from. She lost her leg when she threw herself over her little brothers protecting them from bombs and flames, Nadia could have saved herself but she did not because patriotism exists in her heart. She sacrifices herself to save her brothers.

The hero returns after visiting Nadia in the hospital, the significance of the place is transformed, and the significance of geography changed to a mystery. After the scene becoming a tragic list, it turned into a bright one and the from a closed and besieged place to a spacious place that bears good news about returning to the hometown.

\section{FINDINGS and CONCLUSION}

Kanafani expressed through the place and its symbolism and the cohesion of personality and its connection with it all that he wanted using the various narrative methods, including oneself, the individual narrator's style and dialogue to 


\section{DOI: $\underline{10.51386 / 25815946 / i j s m s-v 4 i 5 p 101}$}

Volume: 4 Issue: 5

September to October 2021

https://www.ijsmsjournal.org

others, and these narrative methods came in a precise way that serves the place and the event together, so each method had its beauty that contributed to adding a new dimension to the place. It showed the advantage of originality and privacy of the place, as we find that the place at Kanafani is not only a decoration of the character and anecdotal events, but rather an essential factor that contains his characters strongly, and the place has an effective textual strength that has a fundamental role in the coherence of the narrative text.

The chosen story reveals a set of relationships of spatial conflict that the anecdotal character lives in. perhaps the most important of them is the struggle on the land, as the city represented the homeland as an exorbitant place for heroes, it narrows the personality and a factor of oppression and marginalization that drives it to depart to the spaces of exile came like places in the previous stories which were open to the city, street, village, and country. It is also found in closed places such as houses, rooms, schools and hospitals which are the characters' residences and movements.

Finally, the researcher refers to the above-indicated places in the anecdotal collection Three Letters from Palestine as in the following table:

Table 1: symbolism in the short story 'Three letters from Palestine'

\begin{tabular}{|l|l|}
\hline Place & Its symbolism \\
\hline The Street & Injustice, loss of freedom, violence, sadness and pain, crime and death \\
\hline The Shop & $\begin{array}{l}\text { The Palestinian revolution, arms, courage and steadfastness, sacrifice and } \\
\text { determination }\end{array}$ \\
\hline Mekor Haim & Enthusiasm, courage, sacrifice, freedom and victory \\
\hline $\begin{array}{l}\text { Haifa Mill and } \\
\text { Reviverian Factory }\end{array}$ & $\begin{array}{l}\text { Connotation of injustice, suffering, killing and death, martyrdom and sacrifices } \\
\text { in the way to the homeland }\end{array}$ \\
\hline Shujaeya & Childhood and innocent memories \\
\hline Kuwait & Shelter, loss and loneliness, mystery and routine \\
\hline The hospital & Challenge, steadfastness and hope \\
\hline
\end{tabular}

\section{REFERENCES}

[1] Abdul Hadi, Mahdi, ed. Palestinian Personalities: A Biographic Dictionary. 2nd ed., rev. and updated. Jerusalem: Passia Publication, 2006.

[2] Brehony, L. (2017) Ghassan Kanafani: Voice of Palestine (1936-1972) www.palestinechronicle.com

[3] Collins. (2014). "Symbol" Collinsdictionary.com.

[4] Darwish, M. (2000), Interview “The Politics of Poetry” Newsweek STAFF ON 3/19/00 AT 7:00 PM EST

[5] Elmahdi, Omer \& Hezam, Abdulrahman. (2019). The Deep Meaning of Symbolism Significance in Men in the Sun. Theory and Practice in Language Studies. 10. 33. 10.17507/tpls.1001.05.

[6] Habib N., Australia S, Ghassan Kanafani in: "The Land of the Sad Orange" http://mrmccrayhistory.weebly.com

[7] Haidar Eid (2020) Re-reading Ghassan Kanafani in the 21st Century, www.palestinechronicle.com

[8] Kanafani (1956): "Letter from Gaza" (marxists.org)

[9] Khan, M. 2017 Ghassan Kanafani.. Pioneer of the study of resistance and Zionist literature, Mudawanat, retrieved from www.aljazeera.net 
DOI: $\underline{10.51386 / 25815946 / i j s m s-v 4 i 5 p 101}$

Volume: 4 Issue: 5

[10] Marshall, S.: 2005, Streets and Patterns: The Structure of Urban Geometry, Ed. Taylor \& Francis.

[11] Neimneh, Shadi. (2017). Postcolonial Arabic fiction revisited: Naturalism and existentialism in Ghassan Kanafani's men in the sun. Indonesian Journal of Applied Linguistics. 7. 238. 10.17509/jail.v7i2.8356.

[12] Shop |Definition of Shop by Merriam-Webster

(alteerah.net) ورقة من الطيرة/من مجموعة قصص أرض البرتقال الحزين/للكاتب الثـيد : غسان كنفاني - طيرة حيفا ـ الطيرة نت13]

(nooreladab.com) 